\title{
ANALISIS KINERJA ACCOUNT REPRESENTATIVE (AR) DALAM UPAYA PENINGKATAN KEPATUHAN WAJIB PAJAK DI KPP PRATAMA MANADO
}

\author{
Alter S. Waghe ${ }^{1}$, Sifrid Pangemanan ${ }^{2}$, Sonny Pangerapan ${ }^{3}$ \\ ${ }^{1}$ Jurusan Akuntansi, Fakultas Ekonomi dan Bisnis,Universitas Sam Ratulangi, Jl. Kampus Bahu, Manado, \\ 95115, Indonesia \\ E-mail : alterwaghe20@gmail.com
}

\begin{abstract}
Tax is a people's contribution to the state that is compelling and the benefits can not be directly felt by the community. Account representative (AR) is an employee who is appointed and designated as an Account representative (AR) in the tax service office and each Account representative (AR) has several taxpayers who must be supervised. The purpose of this study was to analyze the performance of Account Representative (AR) in an effort to increase taxpayer compliance at the KPP Pratama Manado. The analytical method used in this study is descriptive. The results of this study indicate that the Account representative (AR) performance for 2014-2016 has been going well even though in 2014 and 2015 seen from the indicators of proposed special examinations and indicators of visit visit performance Account representative (AR) has not reached the target, but in 2016 already achieve the target and for the level of taxpayer compliance in KPP Pratama Manado in 2014-2016 is still low but each year has increased compliance. Account representative (AR) further enhances performance in efforts to increase compliance by continuously exploring the potential of tax revenue and increasing socialization to taxpayers.
\end{abstract}

Keywords: performance, Account representative (AR), taxpayer compliance

\section{PENDAHULUAN}

Pajak merupakan iuran rakyat kepada negara yang bersifat memaksa dan tidak langsung dapat dirasakan manfaatnya oleh masyarakat. Pajak sangat berperan penting dalam kelangsungan suatu negara. Di Indonesia penerimaan utama dalam APBN adalah dari perpajakan, sehingga perpajakan juga memerlukan peningkatan pengawasan dan mekanisme pengelolaan juga penambahan bantuan yang semakin baik. Pendapatan dari perpajakan bisa dimaksimalkan sesuai menurut keadaan dan kemampuan ekonomi masyarakat. Memaksimalkan pendapatan negara melalui penerimaan pajak karena itu perlu dilakukannya perbaikan perpajakan yang direvisi dari waktu ke waktu atas tetap berlandaskan keadilan sosial. Tujuan dilakukann perbaikan perpajakan tersebut ialah buat memperbanyak dan menambah wajib pajak, sehingga perlu dibuat pelayanan lebih untuk setiap wp baik yang terdaftar maupun belum terdaftar agar penerimaan pajak terus meningkat.

Wujud nyata reformasi birokrasi yang dilakukan oleh DJP yaitu dengan dilakukannya sistem modernisasi perpajakan dengan tujuan untuk mendukung pelayanan yang amat dibutuhkan agar pendapatan negara yang berasal dari pajak bisa ditingkatkan. keadaan ini dapat dilihat juga dari dibentuknya salah satu Sistem Administrasi Perpajakan AR yang menjalankan tugas dan fungsinya melayani penyelesaian hak wajib pajak dan pengawasan terhadap wajib pajak serta tugas konsultasi, apabila wajib pajak mengalami kesulitan atau membutuhkan informasi lainnya terkait pelaksanaan hak dan kewajiban dari wajib pajak. Sehingga, fungsi dari AR sebagai penghubung atau mediator antara KPP dengan wajib pajak (Saleh, 2014).

Keputusan Menteri Keuangan Republik Indonesia dengan Nomor 79/PMK.01/2015 mengatur Account Representative $(A R)$ sebagai petugas yang berada di Kantor Pelayanan 
Pajak Pratama yang menerapkan sistem administrasi modern dan memiliki tugas untuk melakukan pengawasan terhadap kepatuhan pajak, bimbingan untuk wp tentang pajak, dan memberikan himbauan untuk wajib pajak (baik wajib pajak orang pribadi maupun wajib pajak badan). Jumlah AR di KPP biasanya sekitaran 40 dengan tugas melakukan pengawasan beberapa WP. Mereka harus melayani ajib pajak dengan baik dan bersikap proaktif serta mahir soal perpajakan. Agar pemenuhan kewajiban perpajakan dapat meningkat diperlukan peran AR yang baik dalam memberikan bantuan dan informasi untuk WP.

KPP Pratama Manado merupakan salah satu unit vertikal Direktorat Jenderal Pajak di Sulawesi Utara yang bernaung di bawah Kementerian Keuangan Republik Indonesia dan telah menjalankan sistem administrasi modern, memiliki 35 AR. Sesuai dengan tujuannya untuk meningkatkan kepatuhan wajib pajak AR dituntut untuk lebih maksimal dalam melaksanakan tugasnya, karena pemungutan pajak bukan pekerjaan yang mudah, selain pentingnya peran dari petugas pajak perlu juga kesadaran dari wajib pajak. Kurangnya kemauan dari wajib pajak untuk membayar pajak disebabkan karena pendapatan dari pajak tersebut tidak langsung dapat dirasakan manfaatnya, dan juga masih banyak wajib pajak yang belum tahu adanya Account Representative $(A R)$ yang memiliki fungsi sebagai konsultasi pajak serta memberikan bimbingan kepada wajib pajak yang memiliki masalah dengan pajak.

\section{TINJAUAN PUSTAKA}

Akuntansi. Akuntansi bukan merupakan ilmu pengetahuan eksakta atau sains karena dalam proses penalaran dan perancangan, akuntansi banyak terlibat unsur pertimbangan sehingga akuntansi merupakan seni pencatatan, penggolongan, dan peringkasan transaksi bersifat keuangan dengan cara yang berdaya guna dan dalam satuan uang, dan penginterpretasian hasil proses tersebut. (Suwardjono, 2014:5).

Akuntansi Pajak. Menurut Waluyo (2013:35) Akuntasi pajak menjelaskan untuk menetapkan besarnya pajak terutang harus berdasarkan laporan keuangan yang ada dalam suatu perusahan, karena dalam ketentuan perundang-undangan perpajakan terdapat aturan khusus yang berhubungan dengan akuntansi, seperti metode pengukurannya, konsep transaksi dan peristiwa keuangan, serta pelaporannya yang ditetapkan dengan undang-undang.

Pajak. Pajak merupakan iuran rakyatuntuk kas negara dapat dipaksakan berdasarkan ketentuan dari undang-undang serta kagak menerima balas bantuan secara langsung. Pajak dipungut oleh penguasa berdasarkan norma-norma hukum yang ada untuk menutup biaya produksi barang-barang dan jasa kolektif untuk mencapai kesejahtraan umum (Widyaningsih, 2013:2).

Fungsi Pajak. Menurut Widyaningsih (2013:3) beberapa fungsi dari pajak, yaitu:

1. Budgetair (Fungsi penerimaan). Pajak berfungsi sebagai dana yang diperuntukkan bagi pembiayaan pengeluaran-pengeluaran pemerintah. Dalam APBN, pajak merupakan sumber penerimaan dalam negeri. Sebagai fungsi penerimaan pajak digunakan sebagai alat untuk mengoptimalkan penerimaan negara dari rakyatnya tanpa imbal balik secara langsung dari negara kepada masyarakatnya berdasarkan peraturan perundang-undangan perpajakan.

2. Regulerend (Fungsi mengatur). Pajak berfungsi untuk mengatur dalam melaksanakan kebijakan. Misalnya PPnBM untuk barang-barang mewah, hal ini diterapkan pemerintah dalam upaya mengatur agar tingkat konsumsi barang-barang mewah dapat dikendalikan.

3. Fungsi stabilitas. Fungsi ini berkaitan dengan adanya kebijakan untuk menjaga stabilitas harga (melalui dana yang didapatkan dari pajak) sehingga dapat mengendalikan laju pertumbuan inflasi.

4. Fungsi redistribusi. Dalam fungsi redistribusi, dilakukan pemerataan serta adanya keadilan Fungsi ini terlihat dari adanya lapisan tarif dalam pengenaan pajak. Contohnya 
dalam pajak penghasilan, semakin besar jumlah penghasilan dari wajib pajak maka akan semakin besar pula jumlah pajak yang harus ditanggung atau terutang.

5. Fungsi Demokrasi. Fungsi demokrasi yaitu wujud sistem gotong royong. Fungsi ini dihubungkan dengan tingkat pelayanan pemerintah kepada masyarakat pembayaran pajak.

Pengelompokkan Pajak. Mardiasmo (2018:7-8), pengelompokkan pajak dapat dibedakan menjadi 3 macam, yaitu:

1. Menurut Sifatnya

a. Pajak Objektif, yaitu pajak yang berpangkal pada objeknya tanpa memperhatikan keadaan diri wajib pajak.

b. Pajak Subjektif, yaitu pajak yang berpangkal atau berdasarkan pada subjeknya, dalam arti memperhatikan keadaan diri wajib pajak.

2. Menurut Golongannya

a. Pajak Langsung, yaitu pajak tidak dapat dibebankan atau dilimpahkan kepada orang lain tetapi harus dipikul sendiri oleh wajib itu sendiri

b. Pajak Tidak Langsung, yaitu pajak yang dapat dibebankan atau dilimpahkan kepada orang lain.

3. Menurut Lembaga Pemungutnya

a. Pajak Pusat, yaitu pajak yang digunakan untuk membiayai rumah tangga negara dan dipungut oleh pemerintah pusat.

b. Pajak Daerah, yaitu pajak yang digunakan untuk membiayai rumah tangga daerah dan dipungut oleh pemerintah daerah.

Syarat Pemungutan Pajak. Agar pemungutan pajak bisa berjalan dengan baik maka menurut Mardiasmo ( 2018:4-5) syarat untuk pemungutan pajak yaitu:

1. Harus berdasarkan undang-undang (Syarat Yuridis).

2. Adanya keadilan dalam melakukan pemungutan (Syarat Keadilan).

3. Perekonomian tidak boleh terganggu (Syarat Ekonomis).

4. Sistem dari pemungutan harus sederhana.

5. Harus efisien (Syarat Finansial).

Hambatan Pemungutan Pajak. (Mardiasmo 2018:10-11). Hambatan pemungutan pajak:

1. Perlawanan Pasif

Sebagaimana mestinya masyarakat tidak bersedia memenuhi kewajiban perpajakannya, yang dapat disebabkan antara lain sebagai berikut.

a. Sistem perpajakan yang sulit dipahami masyarakat

b. Perkembangan intelektual dan moral masyarakat

c. pengontrolan tidak dapat dilaksanakan dengan baik.

2. Perlawanan Aktif

Perlawanan aktif meliputi perbuatan penghindaran pajak yang secara langsung ditujukan kepada fiskus dan semua usaha. Bentuknya antara lain sebagai berikut :

a. Tax avoidance yaitu usaha meringankan beban pajak dengan tidak melanggar undangundang

b. Tax evasion yaitu usaha dari wajib pajak untuk meringankan pajak dengan cara melanggar undang-undang.

Kinerja. Pengertian kinerja menurut (Wibowo 2015:2) kinerja adalah nilai serangkaian perilaku pekerja yang memberikan kontribusi, baik secara positif maupun negatif, pada penyelesaian tujuan organisasi. Dilakukannya penilaian kinerja untuk memberikan evaluasi untuk prestasi kerja yang dicapai oleh organisasi, kelompok, atau individu. Evaluasi kinerja akan berguna terhadap tujuan dari sasaran kinerja, proses pelaksanaan kinerja serta 
perencanaan. Penilaian kinerja dapat pula dilakukan terhadap proses evaluasi, reviu dan pengukuran kinerja. Untuk melakukan perbaikan kinerja dengan berdasarkan evaluasi kinerja sehingga dapat dilakukan langkah-langkah untuk melakukan perbaikan kinerja di waktu yang akan datang.

Account Representative (AR). Berdasarkan Pasal 1 Peraturan Menteri Keuangan Nomor 79/PMK.01/2015 tentang Account Representative (AR) pada Kantor Pelayanan Pajak Pratama disebutkan bahwa Account Representative (AR) adalah pegawai yang diangkat dan ditetapkan sebagai Account Representative (AR) pada Kantor Pelayanan Pajak. AR memiliki tanggungjawab terhadap wajib pajak yang harus diamati. Penugasan yang diberikan oleh AR dilakukan berdasarkan jenis usaha sehingga pelaksanaan pekerjaan lebih terfokus.

Fungsi Account Representative (AR). Fungsi Account Representative (AR) dapat dibedakan menjadi 2 bagian:

1. Berdasarkan Pasal 3 Peraturan Menteri Keuangan Republik Indonesia Nomor 79/PMK.01/2015 tentang Account Representative (AR) pada Kantor Pelayanan Pajak, Account Representative $(A R)$ yang menjalankan fungsi pelayanan dan konsultasi wajib pajak mempunyai tugas :

a. Melakukan proses penyelesaian permohonan wajib pajak;

b. Melakukan proses penyelesaian usulan pembetulan ketetapan pajak;

c. Melakukan proses penyelesaian usulan pengurangan Pajak Bumi dan Bangunan.

d. Melakukan bimbingan dan konsultasi teknis perpajakan kepada wajib pajak; dan

2. Berdasarkan Pasal 4 Peraturan Menteri Keuangan Republik Indonesia Nomor 79/PMK.01/2015 tentang Account Representative (AR) pada Kantor Pelayananan Pajak, Account Representative $(A R)$ yang menjalankan fungsi pengawasan dan penggalian potensi wajib pajak mempunyai tugas:

a. Menyusun profil wajib pajak

b. Melakukan pengawasan kepatuhan kewajiban perpajakan wajib pajak

c. Analisis kinerja wajib pajak, dan

d. Rekonsiliasi data wajib pajak dalam rangka intensifikasi serta himbauan kepada wajib pajak

Penelitian terdahulu. Intan Farika (2016), dalam penelitian berjudul Sosialisasi Peraturan Perpajakan Dan Kinerja Account Representative Kaitan Dengan Kepatuhan Wajib Pajak. Tujuan dari penelitian ini adalah untuk memaparkan pelaksanaan sosialisasi perpajakan dan kinerja Account Representative dalam membantu Wajib Pajak memenuhi kewajiban perpajakannya di Kantor Pelayanan Pajak Pratama Sidoarjo Barat. Metode yang digunakan dalam penelitian ini adalah Kualitatif. Hasil penelitiannya menunjukkan tingkat pelaporan Surat Pemberitahuan (SPT) semakin meningkat setiap tahunnya yang membuktikan bahwa kesadaran Wajib Pajak semakin meningkat sehingga peran dari Account Representative sebagai pengawas, pembimbing dan konsultasi dalam memberikan sosialisasi peraturan perpajakan dikatakan sudah cukup baik.

\section{METODE PENELITIAN}

Jenis Penelitian. Penelitian ini adalah jenis penelitian deskriptif. Suryabrata (2013:75) penelitian deskriptif adalah jenis penelitian yang bertujuan untuk membuat pecandraan secara factual, sistematis, dan akurat tentang fakta-fakta dan sifat-sifat populasi atau suatu daerah tertentu.

Waktu dan Tempat Penelitian. Penelitian ini dilaksanakan pada KPP Pratama Manado yang beralamat di Jalan Gunung Klabat Kotak Pos 23, Manado, 95117 Sulawesi Utara. Penelitian ini dilakukan pada bulan Juli 2017 sampai dengan selesai.

Prosedur Penelitian. Dengan langkah-langkah sebagai berikut: 
1. Memilih judul serta rumusan masalah.

2. Meminta data yang dibutuhkan sesuai dengan masalah dalam penelitian ini.

3. Melakukan wawancara terhadap petugas pajak yang terkait pengambilan data pada KPP Pratama Manado untuk menganalisis kinerja Account Representative (AR) dalam upaya peningkatan kepatuhan wajib pajak dan memaksimalkan tugas dan fungsinya sebagai pengawasan dan konsultasi perpajakan dengan baik di KPP Pratama Manado.

4. Mengelola data-data yang ada serta menerangkan hasil pengolahan data.

5. Mengammbil kesimpulan serta memberi saran yang dianggap perlu untuk perbaikan dalam masalah yang ada.

\section{Metode Pengumpulan Data}

Jenis Data. Menurut Sinambela (2014:114), ditinjau dari sifatnya data dapat dikategorikan menjadi 2 macam yaitu. Data kuantitatif, data yang diperoleh dalam bentuk angka atau yang diangkakan. Data kualitatif, yaitu data yang diperoleh dalam bentuk informasi dalam bentuk wawancara yang dilakukan terhadap narasumber (responden) yang telah ditentukan sebelumnya. Dalam penelitian ini penulis menggunakan data kualitatif diperoleh melalui berbagai macam teknik pengumpulan data misalnya wawancara, analisis dokumen, diskusi terfokus atau observasi yang telah dituangkan dalam catatan lapangan.

Sumber Data. Sumber data dalam penelitian ini terdiri atas data sekunder dan primer (Indrawan, dkk, 2014:141) Dalam penelitian ini, sumber data yang digunakan adalah data primer berupa gambaran umum institusi, kinerja dari Account representative (AR) yang diperoleh langsung dari KPP Pratama Manado serta data sekunder berupa referensi (bukubuku literatur), artikel, jurnal serta situs di internet yang berhubungan dengan penelitian yang dilakukan.

Teknik Pengumpulan Data. Dalam penelitian ini Teknik pengumpulan data adalah sebagai berikut:

1. Melakukan wawancara kepada petugas pajak, melakukan tanya jawab dengan seksi pengawasan dan konsultasi (waskon) mengenai kinerja dari AR yang ada di KPP Pratama Manado.

2. Dokumentasi, data yang diperoleh dari sub bagian umum seperti sejarah instansi, struktur organisasi instansi, visi dan misi, dan data yang diperoleh dengan seksi pengawasan dan konsultasi (Waskon) KPP Pratama Manado.

Metode dan Proses Analisis. Adapun metode analisis yang dipakai untuk membahas permasalahan yang ada yaitu metode analisis deskriptif di mana metode yang sifatnya menggambarkan, menguraikan suatu keadaan atau data serta menggambarkan dan menggunakan suatu data sedemikian rupa sehingga dapat diambil kesimpulan untuk menjawab permasalahan yang ada (Walakandou, 2013:28). Keadaan atau data yang digambarkan dalam penelitian ini adalah Menganalisis kinerja Account Representative (AR) dengan melihat indikator kinerja utama di KPP Pratama Manado.

\section{HASIL PENELITIAN}

\subsection{Hasil Penelitian}

Indikator Kinerja Account Representative. Dari wawancara dengan kepala seksi pengawasan dan konsultasi (Waskon) di KPP Pratama Manado, indikator penilaian kinerja dari Account Representative (AR) dilihat dari indikator kinerja utama (IKU) di mana setiap awal tahun Account Representative (AR) akan diberikan kontrak kinerja yang akan menjadi acuan bagi setiap AR untuk bisa mencapai target yang sudah ditentukan. Rincian indikator penilaian kinerja dari AR didasarkan dari beberapa hal yaitu: Realisasi penerimaan extra effort pengawasan, himbauan SPT yang selesai ditindaklanjuti, penerbitan STP, usulan riksus 
(pemeriksaan khusus) yang disetujui dan pelaksanaan kunjungan visit. Pada Tabel 1 berikut ini dapat di lihat indikator kinerja utama pegawai di KPP Pratama Manado.

Tabel 1. Indikator Kinerja Utama Pegawai KPP Pratama Manado Tahun 2014-2016

\begin{tabular}{clc}
\hline No & \multicolumn{1}{c}{ Rincian IKU } & Target \\
\hline 1 & Persentase realisasi penerimaan pajak extra effort pengawasaan & $100 \%$ \\
2 & Persentase himbauan SPT yang selesai ditindaklanjuti & $100 \%$ \\
3 & Persentase penerbitan STP & $100 \%$ \\
4 & Persentase usulan riksus (pemeriksaan khusus) disetujui & $100 \%$ \\
5 & Persentase pelaksanaan kunjungan visit & $100 \%$ \\
\hline
\end{tabular}

Sumber : Sub Bagian Umum KPP Pratama Manado 2017

Pada Tabel 1 di atas menunjukan indikator kinerja utama pegawai di KPP Pratama manado untuk tahun 2014-2016 target yang diberikan sebesar 100\% di mana indikator realisasi penerimaan pajak extra effort pengawasaan target yang diberikan sebesar $100 \%$, indikator himbauan SPT yang selesai ditindaklanjuti target yang diberikan sebesar 100\%, indikator penerbitan STP target yang diberikan sebesar $100 \%$, indikator ususlan riksus (pemeriksaan khusus) disetujui target yang diberikan sebesaar 100\% dan untuk indikator pelaksanaan kunjungan visit target yang diberikan sebesar $100 \%$.

Realisasi Penerimaan Extra Effort Pengawasan. Berikut ini Tabel 2 adalah realisasi penerimaan extra effort pengawasan pada KPP Pratama Manado untuk Tahun 2014, 2015 dan 2016.

Tabel 2. Data Realisasi Penerimaan Extra Effort Pengawasaan Pada KPP Pratama Manado Tahun 2014 s.d. 2016

\begin{tabular}{cccc}
\hline Tahun & Target & Realisasi & Persentase (\%) \\
\hline 2014 & 109.145 .326 .434 & 110.508 .941 .309 & $101,24 \%$ \\
2015 & 112.322 .452 .231 & 116.286 .332 .392 & $103,52 \%$ \\
2016 & 128.689 .936 .829 & 132.598 .816 .359 & $103,03 \%$ \\
\hline
\end{tabular}

Sumber : Seksi Pengawasan dan Konsultasi (Waskon) KPP Pratama Manado,2017

Berdasarkan Tabel 2 dapat dilihat bahwa realisaasi penerimaan extra effort pengawasaan untuk tahun 2014, 2015 dan 2016 sudah capai target dan mengalami peningkatan di mana pada tahun 2014 target tercapai sebesar 101,24\%, tahun 2015 target teercapai sebesar 103,52\% pada tahun 2016 target yang tercapai sebesar 103,03\% dan sudah melampaui target yang diberikan. Hal ini menunjukkan kinerja dari Account Representative $(A R)$ sudah sangat baik. Peningkatan disebabkan karena Account Representative (AR) lebih fokus dalam penerimaan perpajakan sebagai salah satu penilaian kinerja dari Account Representative $(A R)$.

Himbauan SPT Yang Selesai Ditindaklanjuti. Berikut ini Tabel 3 adalah himbauan SPT yang selesai ditindaklanjuti oleh AR di KPP Pratama Manado untuk tahun 2014, 2015 dan 2016. 
Tabel 3. Data Himbauan SPT Yang Selesai Ditindaklanjuti oleh Account Representative (AR) di KPP Pratama Manado Tahun 2014 s.d. 2016

\begin{tabular}{cccc}
\hline Tahun & Target & Realisasi & Persentase (\%) \\
\hline 2014 & 1.200 & 2.420 & $201,66 \%$ \\
2015 & 1.400 & 2.901 & $207,21 \%$ \\
2016 & 2.160 & 2.394 & $110,83 \%$ \\
\hline
\end{tabular}

Sumber : Seksi Pengawasan dan Konsultasi (Waskon) KPP Pratama Manado,2017

Berdasarkan Tabel 3 dapat dilihat himbauan SPT yang selesai ditindaklanjuti oleh Account Representative (AR) untuk tahun 2014, 2015 dan 2016 sudah mencapai target diberikan di mana di tahun 2014 target yang tercapai sebesar 201,66\%, tahun 2015 target yang tercapai sebesar 2017,21\%, tahun 2016 target yang tercapai sebesar 110,83\% dan sudah melampaui target yang diberikan. Hal ini menunjukkan bahwa kinerja dari Account Representative (AR) sudah baik.

Penerbitan STP. Berikut ini Tabel 4 adalah penerbitan STP oleh AR di KPP Pratama Manado untuk tahun 2014, 2015 dan 2016.

Tabel 4. Penerbitan STP Oleh Account Representative (AR) di KPP Pratama Manado Tahun 2014 s.d. 2016

\begin{tabular}{cccc}
\hline Tahun & Target & Realisasi & Persentase (\%) \\
\hline 2014 & 840 & 867 & $103,21 \%$ \\
2015 & 1.680 & 1.880 & $111,90 \%$ \\
2016 & 5.760 & 6.794 & $117,95 \%$ \\
\hline
\end{tabular}

Sumber : Seksi Pengawasan dan Konsultasi (Waskon) KPP Pratama Manado,2017

Berdasarkan Tabel 4 dapat dilihat untuk penerbitan STP yang dilakukan oleh Account Representative $(A R)$ untuk tahun 2014, 2015 dan 2016 sudah mencapai target yang ditentukan di mana pada tahun 2014 target yang tercapai sebesar 103,21\% tahun 2015 target tercapai sebesar $111,90 \%$ tahun 2016 target yang tercapai sebesar $117,95 \%$ dan sudah melampaui target yang diberikan. Account Representative $(A R)$ terus menggali potensi penerimaan pajak melalui penerbitan STP. Hal ini dapat dilihat dari dua sisi, pertama kenaikan STP setiap tahunnya bisa menjadi signal masih banyak wajib pajak yang terlambat membayar atau kurang membayar jumlah pajak terutang. Kekurangan pembayaran ini bisa disebabkan karena kurangnnya pengetahuan wajib pajak akan cara penghitungan pajak terutang. Sedangakn bila dilihat dari sisi lain, kita bisa mendapatkan nilai positif dari kinerja Account Representative $(A R)$ dalam pencapaian target penerimaan pajak.

Usulan Riksus Yang Disetujui. Berikut ini Tabel 5 adalah usulan riksus yang disetujui di KPP Pratama Mannado untuk tahun 2014, 2015 dan 2016.

Tabel 5. Usulan Riksus Yang Disetujui di KPP Pratama Manado Tahun 2014 s.d. 2016

\begin{tabular}{cccc}
\hline Tahun & Target & Realisasi & Persentase (\%) \\
\hline 2014 & 28 & 7 & $25,00 \%$ \\
2015 & 28 & 16 & $57,14 \%$ \\
2016 & 16 & 24 & $150,00 \%$ \\
\hline
\end{tabular}

Sumber : Seksi Pengawasan dan Konsultasi (Waskon) KPP Pratama Manado,2017 
Berdasarkan Tabel 5 dapat dilihat usulan riksus disetuji yang dilakukan oleh Account Representative (AR) untuk tahun 2014 dan 2015 realisasinya masih di bawah target, tetapi di tahun 2016 sudah mencapi target diberikan di mana pada tahun 2014 target tercapai hanya sebesar 25,00\% masih di bawah target yang di tentukan, tahun 2015 target tercapai sebesar $57,14 \%$ masih di bawah target yang di tentukan. Tetapi untuk pemeriksaan kusus tahun 2016 target yang tercapai sebesar $150,00 \%$ melebihi target yang di berikan walaupun target tahun sebelumnya yang diberikan lebih besar dari tahun 2016 akan tetapi hal ni menunjukkan kinerja dari Account Representative (AR) tiap tahunnya semakin baik.

Pelaksanaan Kunjungan Visit. Berikut Tabel 6 adalah pelaksanaan kunjungan visit yang dilakukan oleh Account Representative (AR) di KPP Pratama Manado untuk tahun 2014, 2015 dan 2016.

Tabel 6. Pelaksanaan Kunjungan Visit Oleh Account Representative (AR) di KPP Pratama Manado Tahun 2014 s.d. 2016

\begin{tabular}{cccc}
\hline Tahun & Target & Realisasi & Persentase (\%) \\
\hline 2014 & 115 & 100 & $86,95 \%$ \\
2015 & 120 & 99 & $82,50 \%$ \\
2016 & 120 & 382 & $282,96 \%$ \\
\hline
\end{tabular}

Sumber : Seksi Pengawasan dan Konsultasi (Waskon) KPP Pratama Manado,2017

Berdasarkan Tabel 6 dapat dilihat pelaksanaan kunjungan visit yang dilakukan oleh Account Representative (AR) untuk tahun 2014 dan 2015 belum capai target di mana tahun 2014 target yang tercapai sebesar 86,95\% tahun 2015 target yang tercapai sebesar 82,50\% hal ini disebabkan karena banyak wajib pajak yang sulit ditemui dan pada saat dilakukan kunjungan wajib pajak tidak berada di tempat atau berusaha menghindar dari petugas pajak, hal ini yang menyebabkan kinerja dari Account Representative $(A R)$ belum berjalan dengan baik karena kurangnya kerjasama dari wajib pajak untuk memenuhi kewajibannya. Di tahun 2016 pelaksanaan kunjungan visit yang dilakukan oleh Account Representative (AR) sudah bisa mencapai target di mana target yang tercapai di tahun 2016 sebesar 282,96\% melebihi target yang di berikan hal ini menunjukkan kinerja dari Account Representative $(A R)$ tiap tahunnya semakin baik.

Realisasi Penerimaan Pajak di KPP Pratama Manado. Berikut ini Tabel 7 realisasi penerimaan pajak di KPP Pratama Manado untuk tahun 2014, 2015 dan 2016.

Tabel 7. Realisasi Penerimaan Pajak Pada KPP Pratama Manado tahun 2014 s.d. 2016

\begin{tabular}{cc} 
Tahun & Realisasi Penerimaan Pajak (Rp) \\
\hline 2014 & $1.390 .399 .205 .297,00$ \\
2015 & $1.786 .629 .727 .427,00$ \\
2016 & $1.914 .470 .783 .574,00$
\end{tabular}

Sumber : Sub Bagian Umum KPP Pratama Manado, 2017

Berdasarkan Tabel 7 dapat dilihat bahwa realisasi penerimaan pajak di KPP Pratama Manado tiga tahun terakhir mengalami peningkatan di mana pada tahun 2014 realisasi penerimaan pajak sebesar Rp 1.390.399.205.297,00 dan pada tahun 2015 mengalami peningkatan penerimaan sebesar Rp 1.786.629.727.427,00 kemudian pada tahun 2016 meningkat sebesar Rp 1.914.470.783.574,00. Hal ini menunjukkan kinerja dari Account Representative $(A R)$ setiap tahun semakin baik karena tujuan utama dari Account 
Representative $(A R)$ adalah peningkatan dari penerimaan pajak untuk menentukan kinerja dari seorang Account Representative (AR).

Pertumbuhan WP Badan dan OP Non Karyawan. Berikut ini Tabel 8 adalah jumlah wajib pajak di KPP Pratama manado untuk tahun 2014, 2015 dan 2016.

Tabel 8. Pertumbuhan WP Badan dan OP Non Karyawan di KPP Pratama Manado tahun 2014 s.d 2016

\begin{tabular}{ccccc}
\hline Tahun & Badan & $\begin{array}{c}\text { OP Non } \\
\text { Karyawan }\end{array}$ & OP Karyawan & Jumlah \\
\hline 2014 & 11.709 & 26.751 & 83.197 & 121.677 \\
2015 & 12.514 & 27.751 & 83.197 & 134.038 \\
2016 & 13.450 & 29.362 & 95.973 & 138.785 \\
\hline
\end{tabular}

Sumber : Sub Bagian Umum KPP Pratama Manado, 2017

Berdasarkan Tabel 8 dapat dilihat pertumbuhan wajib pajak di KPP Pratama Manado setiap tahunnya mengalami pertumbuhan pada tahun 2014 jumlah wajib pajak sebesar 121.677, di tahun 2015 meningkat 134.038 wajib pajak dan pada tahun 2016 kembali mengalami peningkatan wajib pajak sebesar 138.785 wajib pajak. Hal ini menandakan bahwa kesadaran dari wajib pajak yang terdaftar di KPP Pratama Manado agar dapat mendaftarkan dirinya sebagai wajib pajak (WP Orang Pribadi maupun Badan) semakin meningkat. Dengan demikian bisa dikatakan tingkat kepatuhan akan kewajiban untuk memiliki Nomor Pokok Wajib Pajak (NPWP) juga naik.

Jumlah Surat Pemberitahuan (SPT) Tahunan. Berikut ini Tabel 9 adalan jumlah SPT Tahunan di KPP Pratama manado Tahun 2014, 2015 dan 2016.

Tabel 9. Jumlah SPT Tahunan KPP Pratama Manado tahun 2014 s.d. 2016

\begin{tabular}{cccc}
\hline & \multicolumn{2}{c}{ Jumlah SPT Tahunan } & \\
\cline { 2 - 3 } Tahun & WP OP & WP Badan & Jumlah \\
\hline 2014 & 45.958 & 2.029 & 47.987 \\
2015 & 66.127 & 2.429 & 68.556 \\
2016 & 69.847 & 2.487 & 72.334 \\
\hline
\end{tabular}

Sumber : Sub Bagian Umum KPP Pratama Manado, 2017

Berdasarkan Tabel 9 dapat dilihat jumlah SPT tahunan di KPP Pratama Manado untuk WP Badan mengalami peningkatan pada tahun 2014 dari 2.029 WP dan meningkat di tahun 2015 menjadi sebanyak 2.429 WP dan pada tahun 2016 meningkat menjadi sebesar 2.487 WP dan WP OP juga mengalami peningkatan dari data di atas pada tahun 2014 untuk WP OP sebanyak 45.958 WP OP dan pada tahun 2015 sebesar 66.127 WP OP kemudian kembali meningkat di tahun 2016 sebanyak 69.847 WP OP. Hal ini menunjukkan meningkatnya kasadaran dari wajib pajak untuk memenuhi kewajibannya.

\subsection{Pembahasan}

Analisis kinerja Account Representative (AR). Analisis kinerja dari Account Representative $(A R)$ dapat dilihat pada penilaian indikator kinerja utama dari Account Representative $(A R)$, yaitu:

1. Realisasi penerimaan extra effort pengawasan. Extra effort merupakan upaya yang lebih intensif yang dilakukan dalam rangka pengamanan hasil penerimaan pajak. Extra effort akan dirinci per wajib pajak, per jenis kegiatan serta yang bertanggungjawab dengan 
memanfaatkan data yang tersedia (internal dan eksternal). Mereka melakukan penerimaan extra effort pengawasan melalui penerbitan SP2DK yang diterbitkan berdasarkan data internal yang diperoleh dari SPT wajib pajak termasuk laporan keuangan wajib pajak, data pada aplikasi apportal, sidjp, approweb, serta data eksternal yang diperoleh dari pihak ketiga, seperti data media massa, data dari dispenda, data kendaraan bermotor, debitur Bank Indonesia, dan laporan PPAT. Realisasi penerimaan extra effort pengawasan yang dilaksanakan di KPP Pratama Manado sudah berjalan dengan baik, karena pada realisasi untuk tahun 2014, 2015 dan 2016 sudah di atas target yang diberikan. Pada tahun 2014 target yang dicapai sebesar 101,24 \% kemudian di tahun 2015 target yang dicapai sebesar 103,52 \% dan di tahun 2016 target yang dicapai sebesar 103,03\%.

2. Himbauan SPT yang selesai ditindaklanjuti. Mereka melakukan dengan menerbitkan Surat Permintaan Penjelasan atas Data dan Keterangan (SP2DK). SP2DK diterbitkan gunanya untuk meminta penjelasan atas data dan keterangan kepada wajib pajak terhadap adanya dugaan belum dipenuhinya kewajiban perpajakan menurut dengan ketentuan peraturan perundang-undangan di bidang perpajakan. KPP Pratama Manado memberikan kesempatan kepada wajib pajak untuk menyampaikan tanggapan atas SP2DK paling lama 14 hari setelah tanggal kirim SP2DK melalui pos, jasa ekpedisi atau jasa kurir dan tanggal SP2DK disampaikan secara langsung oleh petugas. Kemudian mengawasi tindaklanjut sampai wajib pajak memberikan klarifikasi dan kemudian melakukan pembayaran pajak yang kurang bayar dan pembetulan SPT. Jika terjadi keterlambatan penyampaian/pembayaran SPT Account Representative (AR) menerbitkan Surat Tagihan Pajak (STP). Himbauan SPT yang selesai ditindaklanjuti di KPP Pratama Manado untuk ke tiga tahun sudah berjalan dengan baik karena mencapai target. Untuk tahun 2014 target yang dicapai sebesar 201,66 \% kemudian di tahun 2015 target yang dicapai sebesar 207,21\% dan di tahun 2016 target yang dicapai sebesar 110,83\%.

3. Penerbitan STP. Surat Tagihan Pajak (STP) merupakan surat untuk melakukan tagihan pajak dan sanksi administrasi berupa bunga dan dendah juga berfungsi sebagai koreksi atas jumlah pajak terutang, sarana mengenakan sanksi kepada wajib pajak, serta sarana menagih pajak. STP diterbitkan untuk keterlambatan pelaporan SPT. STP diterbitkan setelah dilakukan penelitian administrasi, setelah dilakukan verifikasi, pemeriksaan, pemeriksaan ulang dalam rangka penerbitan SKP dalam hal PPh dalam tahun berjalan tidak atau kurang dibayar, dari hasil penelitian SPT terdapat kekurangan pembayaran pajak sebagai akibat salah tulis/salah hitung. STP memiliki dasar hukum yang sama dengan SKP (Surat Ketetapan Pajak) sehingga dalam hal penagihan dapat dilakukan dengan surat paksa. Berdasarkan hasil penelitian Penerbitan STP yang dilaksanakan di KPP Pratama Manado sudah berjalan dengan baik. Pada Penerbitan STP setiap tahunnya mengalami peningkatan, mereka melakukan penerbitan STP dengan mengawasi kepatuhan pelaporan dan pembayaran wajib pajak kemudian menerbitkan STP pada wajib pajak yang terlambat bayar, terlambat lapor termasuk tidak melakukan pelaporan. Penerbitan STP yang ditetapkan di KPP Pratama Manado untuk tahun 2014-2016 sudah di atas target yang di berikan pada tahun 2014 target yang dicapai sebesar 103,21\% kemudian di tahun 2015 target yang dicapai sebesar 111,90\% dan di tahun 2016 target yang dicapai sebesar 117,95\%.

4. Usulan riksus yang disetujui. Pada saat usulan riksus yang disetujui diawali dengan penerbitan SP2DK kemudian apabila wajib pajak tidak menanggapi SP2DK tersebut dan tidak mengakui data yang diklarifikasi, wajib pajak diusulkan untuk dilakukan pemeriksaan khusus oleh fungsional pemeriksa pajak dengan terlebih dahulu dibuatkan analisa resikonya. Analisa resiko dibuat oleh Account Representative (AR) dan disetujui oleh kepada seksi pengawasan dan konsultasi, selanjutnya disampaikan kepada UP2. Usulan riksus yang disetujui yang ditetapkan di KPP Pratama Manado untuk tahun 2014 
dan 2015 belum tercapai tapi terjadi perkembangan untuk tiap tahunnya. Pada tahun 2014 target yang dicapai sebesar 25,00 \% kemudian di tahun 2015 target yang dicapai meningkat sebesar 57,14\% di tahun 2016 target yang di capai sebesar 105,00\%.

5. Pelaksanaan Kunjungan Visit. Petugas melakukan kunjungan atau visit untuk mendatangi tempat tinggal, tempat kedudukan, tempat kegiatan usaha, pekerjaan bebas wajib, dan atau tempat lain yang dianggap perlu yang memiliki kaitan dengan wajib pajak. Visit dilakukan agar bisa meminta penjelesan atas keterangan atau data dalam rangka pengalian potensi pajak. Potensi pajak dapat dilakukan dalam hal: penyampaian SP2DK akan dilakukan secara langsung kepada wajib pajak, memutahirkan data perpajakan wajib pajak, memberikan pembinaan berupa penyuluhan bimbingan dan konsultasi kepada wajib pajak. Kemudian Account Representative $(A R)$ membuat laporan pelaksaan kunjungan (visit) yang berisi tentang pelaksaan dan hasil kunjungan yang memuat kesimpulan dan usulan/rekomendasi. Pelaksanaan kunjungan visit yang ditetapkan di KPP Pratama Manado sendiri pada tahun 2014 dan 2015 belum tercapai tapi pada tahun 2016 sudah sudah tercapai. Pada tahun 2014 target yang dicapai sebesar 86,95 \% kemudian di tahun 2015 target yang dicapai sebesar 82,50\% dan di tahun 2016 target yang dicapai sebesar 282,96\%.

Berdasarkan data di atas dapat dilihat pada tahun 2016 menunjukkan kinerja dari Account Representative (AR) sudah berjalan dengan baik. Hal ini disebabkan karena usahausaha pada tahun 2014 belum memberikan hasil sehingga baru terealisasikan di tahun berikutnya. Beberapa hal yang menyebabkan tidak tercapainya target dari indikator penilaian kinerja utama ditahun 2014 dan 2015 sehingga menunjukkan hasil yang cukup efektif adalah sebagai berikut:

1. Target yang dibebankan kepada Account Representative (AR) terlalu tinggi sedangkan tugas dari Account Representative (AR) sangat banyak.

2. Database yang ada di KPP Pratama Manado masih belum canggih seperti negara-negara lain. Account Representative (AR) harus mencari penerimaan maksimal dengan data yang minimal.

3. Kurangnya kesadaran wajib pajak untuk melaksanakan kewajiban perpajakannya.

\section{KESIMPULAN DAN SARAN}

\subsection{Kesimpulan}

Berdasarkan analisis data dan pembahasan yang telah diuraikan, maka kesimpulan atas penelitian ini sebagai berikut.

1. Kinerja Account representative (AR) setiap tahunnya semakin baik, dilihat dari pembahasan di atas walaupun tingkat kepatuhan wajib pajak masih terbilang rendah, namun tingkat kepatuhan wajib pajak dari tahun 2014, 2015 dan 2016 mengalami peningkatan kepatuhan, dan dapat dikatakan bahwa wajib pajak yang terdaftar di KPP Pratama Manado untuk tingkat kepatuhannya tiap tahun mengalami peningkatan.

2. Pencapaian Kinerja Account Representative (AR) yang dilihat dari indikator kinerja utama pada tahun 2014 tergolong cukup baik, kemudian di tahun 2015 cukup baik dan pada tahun 2016 tergolong sangat baik dan berdasarkan data di atas dapat dilihat pada tahun 2016 menunjukkan kinerja dari Account Representative (AR) sudah berjalan degan baik.

\subsection{Saran}

Berdasarkan hasil penelitian, maka saran yang dapat diberikan sebagai berikut.

1. Sebaiknya jumlah petugas Account representative $(A R)$ diperbanyak agar tugas pengawasan dan konsultasi terhadap wajib pajak bisa lebih intensif dan alangkah baiknya jika petugas Account Representative (AR) lebih meningkatkan kinerja terlebih dalam 
upaya meningkatkan kepatuhan wajib pajak sehingga dari tahun ke tahun jumlah wajib pajak yang tidak patuh berkurang dan jumlah wajib pajak yang patuh meningkat.

2. Database yang ada di KPP Pratama Manado harus lebih ditingkatkan lagi agar banyak informasi yang didapat oleh Account Representative (AR) tentang wajib pajak dan dapat mempermudah Account Representative (AR) untuk mengetahui kewajiban dari wajib pajak yang seharusnya dibayar oleh wajib pajak.

3. Meningkatkan sosialisasi dan pembinaan kepada wajib pajak tentang pentingnya membayar pajak serta meningkatkan pengawasan terhadap wajib pajak yang tidak melakukan kewajiban perpajaknnya dengan benar.

\section{DAFTAR PUSTAKA}

Indrawan, Rully dan Yaniawati, Poppy, 2014. Metodologi Penelitian Kuantitatif dan Kualitatif, dan Campuran untuk Manajemen, Pembangunan dan Pendidikan. PT. Refika Aditama. Bandung.

Intan Farikha, 2016. "Sosialisasi Peraturan Perpajakan Dan Kinerja Account Representative Kaitan Dengan Kepatuhan Wajib Pajak" Jurnal Ilmu dan Riset Akuntansi : Volume 5, Nomor 3, Maret 2016.

Kementerian Keuangan Republik Indonesia. 2015. Peraturan Menteri Keuangan Republik Indonesia Nomor 79/PMK.01/2015 tentang Account Representative. Pada Kantor Pelayanan Perpajakan.

Mardiasmo, 2018. Perpajakan, Edisi Terbaru. Andi, Yogyakarta.

Randy, Walakandou. 2013. "Analisis Kontribusi Pajak Hotel Terhadap Pendapatan Asli Daerah (PAD) di Kota Manado" Jurnal EMBA ., Vol.1 No.3 ISSN 2303-1174.

Saleh, Muhammad, Septiyeni. 2014. "Analisis Penerapan Modernisasi Administrasi Perpajakan dan Implikasinya terhadap Kinerja Account Representative". Jurnal Dinamika Akuntansi dan Bisnis. Vol. 1 No. 1. Maret 2014.

Sinambela, Lijan Poltak. 2014. Metodoligi Penelitian Kuantitatif, untuk bidang Ilmu Administrasi Kebijakan Publik, Ekonomi, Sosiologi, Komunikasi, dan Ilmu Sosial Lainnya. Graha Ilmu. Yogyakarta.

Suwardjono. 2014 Akuntansi Pengantar Bagian 1, Edisi Ketiga, Penerbit BPFE. Yogyakarta. Suryabrata. S.,2013, Metodologi Penelitian. PT. Raja Grafindo persada, Jakarta, Wibowo, 2015. Manajemen Kinerja, Edisi kelima. Penerbit Rajawali Pers.

Widyaningsih, A., 2013. Hukum Pajak Dan Perpajakan. Alfabet. Bandung. Waluyo, 2013. Perpajakan Indonesia. Edisi Kesebelas. Salemba Empat, Jakarta 